\title{
The Centre of the Centre: The Buddhist Temple and the Chinese New Year in the Prato Urban Space
}

\section{DANIELE PARBUONO}

Chongqing University of Arts and Sciences, University of Perugia daniele.parbuono@botmail.com

Keywords: Anthropology of Migration, Chinese in Prato, Buddhist Temple, Chinese New Year, Urban Spaces

DOI: https://dx.doi.org/10.15239/hijbs.01.01.10

\begin{abstract}
This article analyzes some important aspects of the relationships and spatial disputes between the temple of the 'Associazione Buddista della comunità cinese' and Prato's complex context. In the last three decades, the city — with a significantly increased population due to post-World War II internal migration-has been involved in a steady Chinese migration that transformed spatial relationships and ways of living. In this context, the temple association organizes different group activities tied to worship or the needs of the migration condition. During festive events, the temple receives pilgrims from other Italian cities, and with great care hosts the political and religious authorities, emphasizing the quantitative and socio-cultural weight of the Chinese community. The propulsive energy of the temple emerges in observation of events and political dynamics related to the Chinese New Year. When the costume parade-promoted by the Association-crosses between the professional and private lives of Prato's families, it evokes the symbolic right to use the city's space throughout the year.
\end{abstract}


Nous sommes à une époque où l'espace se donne à nous sous la forme de relations d'emplacements. ${ }^{1}$

\section{Foreword}

6 This year the parades are back in "Piazza del Comune" ["Town

[ Square"]' Moreno ${ }^{2}$ said when I asked him about the Chinese New Year celebration organized in Prato, Italy by the Temple of the Buddhist Association of the Chinese community (Associazione Buddista della comunità cinese in Italian) $\mathrm{Pu} \mathrm{Hua} \mathrm{Si}{ }^{3}$ Considering the choreographic folklore of the parades scheduled for one of the major Chinese holidays-also reintroduced in many contexts of migration - to be of secondary importance, his reply is a rather important reflection on the political relations between the spaces of worship and the city space management.

Based on the theory of 'spatial turn' and the work of Kim Knott, ${ }^{4}$ my article reflects on the positions of the migrator community's urban space in Prato and the ways it is utilized for Buddhist Temple activities. This article will begin with some specific historical events and meaningful changes generated by the varying local power balance. In Knott's researches-which, as pointed out by Alessandro Cancellieri and Chantal Saint-Blancat, ${ }^{5}$ connect the perceived, conceived and lived space of Henri Lefebvre ${ }^{6}$ with a reflection on the re-

1 Foucault, 'Des espaces autres'.

2 Moreno (54-year-old employee, former town councillor of centre-left party, Italian, living in Prato), in discussion with the author. December 18, 2015. The names mentioned are real. With regard to people of Chinese origin, I used Italians pseudonyms that each of them uses daily. Just to give an example, on the business card of Antonio (often mentioned in the text) we can read: 'Zhou Yimin detto [named] Antonio'. All interviews are translated in English by me.

3 This article - here revised and correct - has been already published in Italian on Anuac journal: Parbuono, 'Il centro del centro'.

4 Knott, The Location of Religion.

5 Cancellieri and Saint-Blancat, 'La scrittura religiosa della città'. 
lation (proposed by Jonathan Z. Smith) among rituals, ${ }^{7}$ religiousness and space-the secularization of religious events can be seen through the conceptual and political definition of public space. This happens when ritual practices become the means to physically acquire spatial territory and claim forms of spatial justice. 'Spatial justice' was highly debated by social geography scholars over the past four decades. ${ }^{8}$ This concept connects the heuristic power of 'social justice'-which David Harvey began referring to as 'territorial justice' in the 1970 s $^{9}$ with the political dimension of space construction discussed by Lefebvre's La Production de l'espace. Furthermore, this setting does not function as pre-existing or separated from the effectiveness of human relations, but rather as a complex space which redefines itself through interactions between local power dynamics.

In this sense, the Chinese migrants are '[...] residents of cities and actors within and across space rather than as aggregated ethnic "communities"'. ${ }^{10}$ As we will see, the long search for a 'right' place to establish the temple and the effort to bring New Year celebrations to symbolically meaningful places of the city are the outcome of active interrelationships between social actors and the complexities of the surrounding urban space. Beginning with the analysis of historical and economic conditions that influenced the characteristics of certain urban areas, I used a catalyst element of spatial contention during recent years to examine aspects of the temple association in particular. By bringing together movements of the 'internal border' that '[...] tende ad assumere significati soprattutto ideologici e simbolici' ${ }^{11}$ — as explained by Alexander Koensler in his

6 Lefebvre, La production de l'espace.

7 Smith, To Take Place.

8 See, for example: Dikeç, 'Justice and the Spatial Imagination'; Pirie, 'On Spatial Justice'; Soja, Seeking Spatial Justice. For a general overview of the subject see Cancellieri and Ostanel, 'The Struggle'.

9 Harvey, Social Justice and the City.

10 Çağlar and Glick Schiller, Introduction, 3.

11 Koensler, Amicizie vulnerabili, 56. My translation: '[...] tends to take on meanings above all ideological and symbolic'. 
text on Israel ethnography starting from work by Oren Yiftachel ${ }^{12}$ and Dan Robinowitz ${ }^{13}$ - with the complexity of the Chinese migration in Prato, systematized in recent work by Loretta Baldassar, Graeme Johanson, Narelle McAuliffe and Massimo Bressan, ${ }^{14}$ we can use the concept of 'contention' to convey the meaning of the socio-political process through which the city constantly changes and takes form.

Religion, as a social factor, enters these processes fully developed and the physical temple allows for new relationships to progress through this direct link to the places of origin. On the other hand, the temple also provides the opportunity to form strategic connections to the urban dynamics of Prato. Starting from its activities, Chinese migrants open the door to the city by inserting themselves into its important physical, human and relational spaces.

On festive occasions, the Buddhist Association prepares the temple to receive Chinese visitors coming from various Italian cities. They are also very welcoming to the political and religious authorities who are invited. In other circumstances, during festive 'threshold' time, the Association uses the temple's centrifugal force to symbolically, and physically, conquer important urban spaces.

For this reason, using ethnographic experiences and comparisons with international literature, ${ }^{15}$ I observed how Chinese New Year celebrations revealed two opposing political positions occurring within the same context: on the one hand, Chinese migrants sought

\footnotetext{
12 Yiftachel, "The "Internal Frontier".

13 Robinowitz, Overlooking Nazareth.

14 Baldassar, Johanson, McAuliffe and Bressan, Chinese Migration.

15 The research on Chinese migration in Prato, with specific reference to the Temple Pu Hua Si, started in August 2012, in collaboration with the Sinologist Ester Bianchi. It continues today-within the PRIN (Progetto di rilevante Interesse Nazionale) coordinated by Cristina Papa, Migrazioni, legami familiari e appartenenze religiose: interrelazioni, negoziazioni e confini, 2014-2017-following these lines: institutional evolution (from association to association-temple, to monastery); relations with the institutions, the policies and the urban space of Prato; formality and informality in personal relationships.
} 
visibility and presence in the space; whereas, on the other hand, there were attempts to control the urban impact of Chinese migration.

\section{Prato, migration ... then the Chinese}

Over the past twenty-five years, large Chinese migrations to Prato transformed spatial relationships, ${ }^{16}$ the concept of living, the face and the anthropic 'rhythm' of the city. ${ }^{17}$ We must first address the circumstances that led to this great Chinese migration to Prato, specifically, over the last three decades. As recalled by Knott, 'Space is not an empty container or tabula rasa in which other things are placed or against which they happen'. ${ }^{18}$ For this reason, a summary of the conditions that fostered the increased flow of Chinese is useful for analysis.

Immediately after the Second World War, Prato became an attractive location because of its geographical position and production experience. As Moreno pointed out, 'the textile history in Prato came from afar'. This was in relation to an internal migration where southern Italian habitants started traveling north to meet the work demands of cities undergoing economic expansion. In the early 1970s, the population of Prato was over 143,000. In comparison, the 1951 census only accounted for a population of 77,000. ${ }^{19}$ This resulted in an increase of buildings; if ' $\mathrm{Nel} 1945$ erano stati costruiti soltanto il 28,7\% degli edifici esistenti oggi, [...] nel 1970, dopo soli 25 anni, ben l'80\%, ${ }^{20}$

The recently developed quarters near the old town centre at this stage had a typical contiguity between homes and places of craft or

16 For work on Chinese migration see Latham and $\mathrm{Wu}$, Chinese Immigration; Thunø, 'Beyond Chinatown'. For work on Chinese migration in Prato see Ceccagno, Migranti a Prato; Marsden, L'analisi.

17 Berti, Pedone and Valzania, Vendere e comprare.

18 Knott, Spatial Theory, 160.

19 Sambo, 'Gli immigrati'.

20 Bressan and Tosi Cambini, 'Eterogeneità culturale', 210. My translation: 'In 1945 had been built only $28.7 \%$ of today existing buildings, [...] in 1970, after only 25 years, as many as $80 \%$. 
industrial production. The town planner, Bernardo Secchi,_called to draw up the town plan in the 1990s-summarized the peculiarities of the new semi-central areas with the concept of mixité: meaning the town buildings had a strong overlap of functions (housing and production), making for a pervasive use of space with an overload of service structures and viability. ${ }^{21}$ The mixité is the result of extensive demographic and economic growth, combined with small and medium entrepreneurs who lacked the intention to expand.

Prato thus acquired the characteristics of a 'factory city', which Andrea also talks about in his interview: ${ }^{22}$

there is a mixture between the factory and houses that were emptying [...] being an old industrial area, factories were built next to the houses and they represented a danger; there was the need to create new urban spaces like squares.

Andrea's statement introduced two important topics: the crisis of the 'company town' model and the need to requalify its features. However, this occurred in the early 1990s, when the Chinese migration issue was still marginal. Previously, in the 1970s, demographic and economic transition processes had increased and the mass circulation of goods required new production patterns, which led to many of the contemporary urban landscapes. ${ }^{23}$ Even medium-sized cities, such as Prato, which 'looks small, but it's the third largest city in central Italy after Rome and Florence', ${ }^{24}$ concentrated its production activities in specially planned areas and better equipped itself from a logistical perspective. This trend developed due to the doubling of Prato's population following the war. However, in the 1980s, the city's urban spaces saw a complete shift in functionality and reshaped to accommodate

21 Secchi, Un progetto.

22 Andrea (63-year-old artist, founder of contemporary artist group Dryphoto, Italian, living in Prato), in discussion with the author. December 28, 2015.

23 Papa, Letture.

24 Moreno (54-year-old employee, former town councillor of centre-left party, Italian, living in Prato), in discussion with the author. December 18, 2015. 
new circumstances. The areas of mixité lost inhabitants and working activities; the streets, "a pettine"-in parte a cul de $\operatorname{sac}^{\text {"25 }}$ were full of abandoned warehouses and over-exploited areas because of the decentralization of establishments. This abandonment clearly marked the need for the city to reassess its framework.

In response, 'this empty space is filled with the Chinese', Andrea said. Perhaps it is primarily filled with Chinese, but not completely. In fact, during the 1990s, the urban areas, from which old and new inhabitants of Prato moved away, regained new meaning through the increase of foreign migration flows: ${ }^{26}$ 'Ma se nel $1997 \mathrm{i}$ permessi di soggiorno rilasciati dalla questura sono 5.135, nel 1998 arrivano a 8.506 e nel 1999 raggiungono i 13.360 di cui 7.900 cinesi'. ${ }^{27}$

Today, the demographic situation recorded by the Town Council of Prato is summarized in Figure 1, Table $1 .^{28}$ Data confirmed the trend of foreign populations, Chinese in particular, 'occupying' the central or semi-central spaces that are now 'empty' (Table 2). The official estimates said that Chinese amount to about $40 \%$ of the foreign population. Over time the quantitative gap continued to widen (Figure 2). 'Parbuono: they say that thirty thousand Chinese are living in Prato [...]. Antonio: forty thousand!'. ${ }^{29}$ Moreno assumed the same numbers, and Kevin Latham and Bin Wu confirmed this estimate. ${ }^{30}$

25 Bressan and Tosi Cambini, 'Eterogeneità culturale', 217. My translation: 'comb-like streets, partly cul de sac'

26 Ceccagno, 'Migranti a Prato'.

27 Rastrelli, 'L'immigrazione a Prato', 71. My translation: 'But if in 1997 the residence permits issued by the police were 5.135, in 1998 they amount to 8.506 and in 1999 they reach 13.360 of which 7.900 Chinese'.

28 Commune di Prato, 'Popolazione staniera al 31.12.2018' [foreign population on 31.12.2018]. http://statistica.comune.prato.it/ act $=f \& f i d=6370$; consulted on February 1, 2016.

29 Antonio. (65-year-old interpreter, one of the leaders of the Association-Temple, Chinese, living in Florence), in discussion with the author. August 18, 2013. The words of Antonio, deceased in 2016, are taken from interviews of August 6, 2012 (n.1) and, as in this case, of August 18, 2013 (n.2).

30 Latham and $\mathrm{Wu}$, Chinese Immigration. 
FIG. 1 Residents from 2000 to 2015.

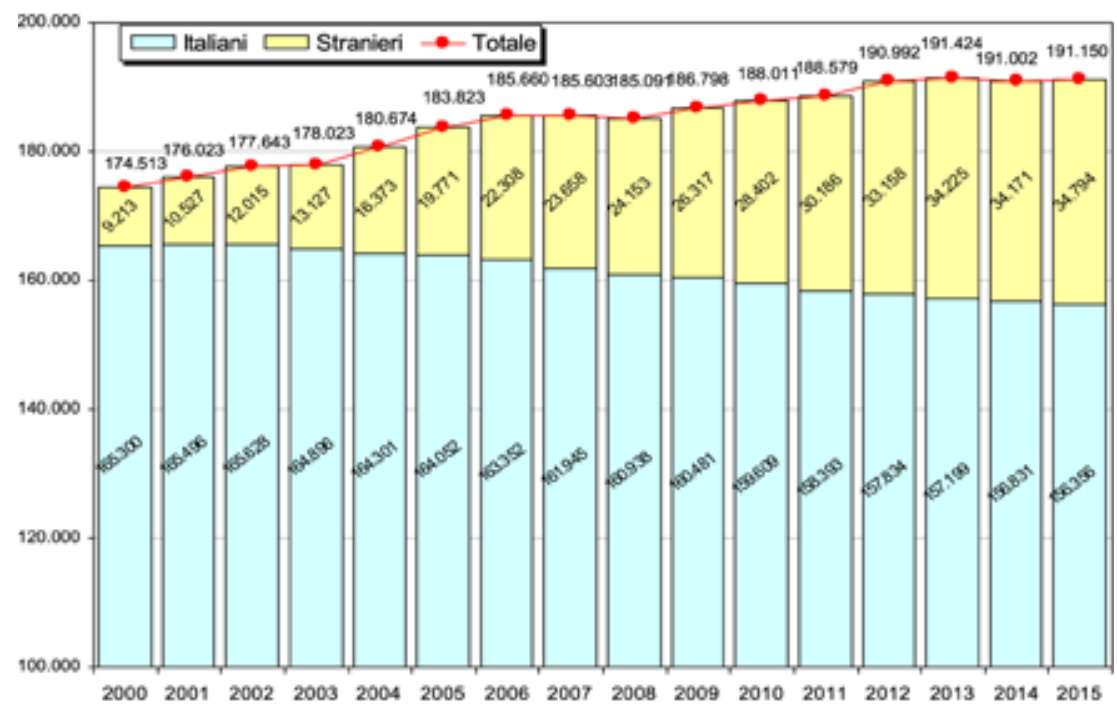

TABLE. 1 Foreign population from 2009 to 2015.

\begin{tabular}{lccccccc}
\hline $\begin{array}{l}\text { Foreign } \\
\text { Population }\end{array}$ & 2009 & 2010 & 2011 & 2012 & 2013 & 2014 & 2015 \\
\hline Chinese & 10,877 & 11,882 & 13,056 & 15,029 & 16,182 & 15,957 & 16,918 \\
\hline Albanian & 4,494 & 4,646 & 4,805 & 4,936 & 4,926 & 5,008 & 4,827 \\
\hline Romanians & 2,481 & 2,806 & 3,074 & 3,328 & 3,358 & 3,429 & 3,415 \\
\hline Pakistani & 1,828 & 1,957 & 1,951 & 2,206 & 2,151 & 2,064 & 1,989 \\
\hline Moroccans & 1,535 & 1,540 & 1,589 & 1,618 & 1,593 & 1,564 & 1,505 \\
\hline Other foreigners & 5,102 & 5,571 & 5,711 & 6,041 & 6,015 & 6,149 & 6,140 \\
\hline Total & 26,317 & 28,402 & 30,186 & 33,158 & 34,225 & 34,171 & 34,794 \\
\hline
\end{tabular}


TABLE. 2 Total population divided by area December 31, 2015.

\begin{tabular}{lrrrr}
\hline Area & Total population & Italian & Foreigners & Chinese \\
\hline North & 38,173 & 32,566 & 5,607 & 2,147 \\
\hline East & 31,547 & 27,543 & 4,004 & 941 \\
\hline South & 45,437 & 38,877 & 6,560 & 3,762 \\
\hline West & 36,698 & 30,544 & 6,154 & 3,623 \\
\hline Centre & 39,093 & 26,641 & 12,452 & 6,444 \\
\hline of which Old Town Centre & 7,418 & 5,447 & 1,971 & 398 \\
\hline Homeless or unreachable & 202 & 185 & 17 & 1 \\
\hline Prato & $\mathbf{1 9 1 , 1 5 0}$ & $\mathbf{1 5 6 , 3 5 6}$ & $\mathbf{3 4 , 7 9 4}$ & $\mathbf{1 6 , 9 1 8}$ \\
\hline
\end{tabular}

FIG. 2 Foreign population. From 1985 to 2015.

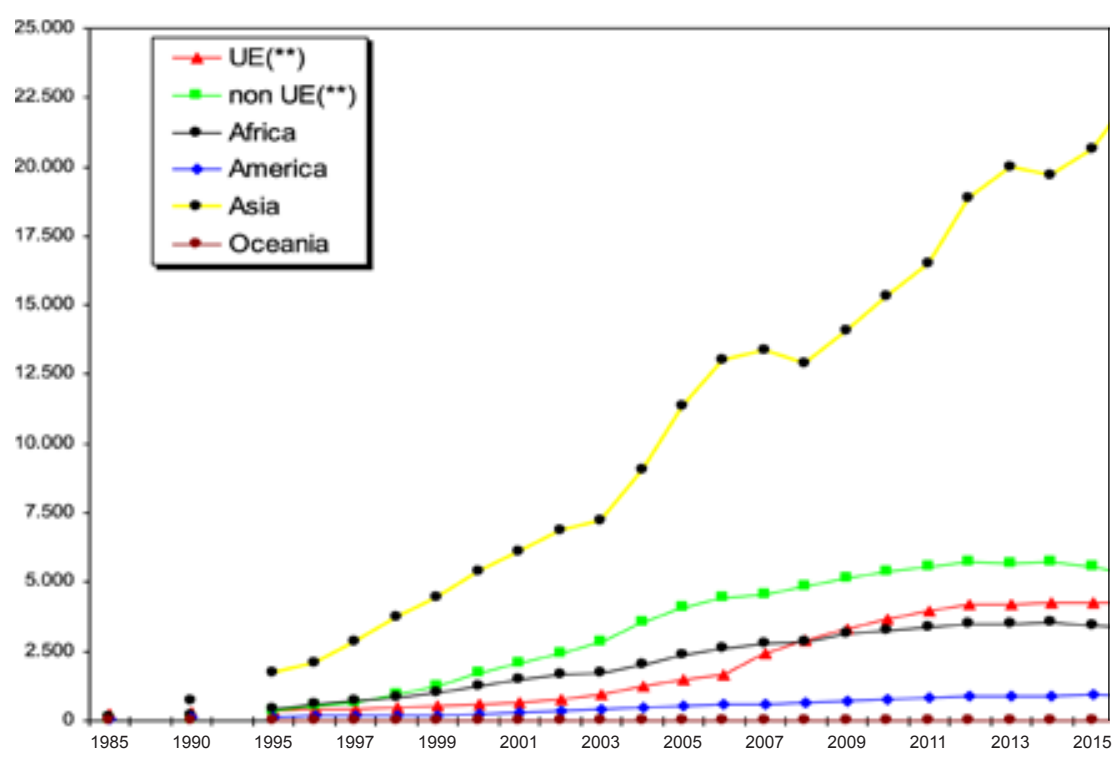


Concerning the gap between official and alleged estimates, the positions take contrasting directions. For example, Paolo Sambo believed that the self-persuasion rhetoric about quantitative overestimation gave ' $[. .$.$] una parvenza di fondamento scientifico al dibattito e pro-$ mosso politiche più repressive $[\ldots]]^{3}{ }^{31}$

The combination of complex living conditions of the country of origin, the search for work in an area that attracts manpower, the family reunifications, and the contingencies of the economic-production phase dictated by the new global expansion policies of the 1980 s, ${ }^{32}$ triggered the massive Chinese presence in Prato.

In other words, a new type of highly mobile commercial migrant relying mainly on China's new position in the global division of labor as the world's manufacturing house of inexpensive and low-quality goods has emerged as part of contemporary Chinese migration. ${ }^{33}$

Various causes confirmed Prato as one of the primary Italian destinations for the Chinese labour migration: ${ }^{34}$ the possibility to use the dismissed craft-industrial factories; the crisis of previous companies; the increasingly common Italian trend towards production relocation; ${ }^{35}$ and, above all, '[...] le caratteristiche del lavoro svolto nelle ditte cinesi (estrema flessibilità, impiego massiccio del cottimo, lavoro familiare, sistemi particolari di organizzazione del lavoro per ridurre i costi e regolare i rapporti fra datori di lavoro e dipendenti) $[\ldots]^{\prime} .^{36}$

31 Sambo, 'Gli immigrati cinesi', 119. My translation: '[...] a semblance of scientific basis to the debate and promoted mainly repressive policies [...]'.

32 Latham and $\mathrm{Wu}$, Chinese Immigration.

33 Thunø, 'Introduction', 14.

34 Bressan and Krause, 'Ho un luogo dove lavoro'.

35 Gambino and Sacchetto, Un arcipelago produttivo; Redini, Frontiere.

36 Rastrelli, 'L'immigrazione a Prato', 84. My translation: '[...] the characteristics of the work done in Chinese firms (extreme flexibility, high use of piecework, family work, special work organization systems to reduce costs and regulate relations between employers and employees) $[\ldots]$ '. 
It would be a mistake to conclude that the Chinese business condition-which is closely related to the migration dynamics-is relegated to a sort of self-sufficient isolation of commercial-production. The professional potential of Chinese immigrants became a resource for many Italian companies to remain competitive in market dynamics, where margins of profit for the manufacturing industry were decreasing. At the same time, the considerable financial capital of Chinese entrepreneurs ensured the stability of the luxury market through growing sales of expensive cars, precious jewels and luxury housing. ${ }^{37}$

Over the years, these complex relationships and socio-economic oxymora have been at the centre of the local political debate. These issues even reached national notoriety during major events, such as the famous fire of the 'warehouse-dorm' (capannone-dormitorio) ${ }^{38}$ in 2013, where seven Chinese workers died. This fire event is particularly notable because the building where it occurred was in an area of the city with all the characteristics of mixité: that is the 'Macrolotto 0 ', an area that, during the 1990s, was 'emptied' of its decades-long residents and 'filled' with the many incoming Chinese. Nowadays many people refer to the 'Macrolotto 0' area-located near the old town centre, close to 'via Filzi' and 'via Pistoiese' - as 'Chinatown'. ${ }^{39}$ In my opinion, this is no longer a correct term for the area, because many Chinese moved to other districts and wealthy migrants bought fine houses in outlying areas (for example in Carmignano or in the Seano suburb). However, it is still true that 'more than half of the residents of the 'Macrolotto 0' are Chinese' ${ }^{40}$ and the local belief, as

37 Brandi and Iacopini, 'Dal cocomero al Suv'; Resta, Il vantaggio dell'immigrazione.

38 "Many newspapers used this definition. Only as an example I report the title Rogo in una fabbrica di Prato: sette morti nel capannone-dormitorio. Continuano le ricerche, December 1, 2013.

39 The term is often used by the national media, but also by the international (http://www.zeit.de/2014/30/chinesen-italien-textil-industrie; consulted on January 1, 2017).

40 Vittoria (67-year-old cultural operator, president of Dryphoto, Italian, living in Prato), in discussion with the author. December 29, 2015. 


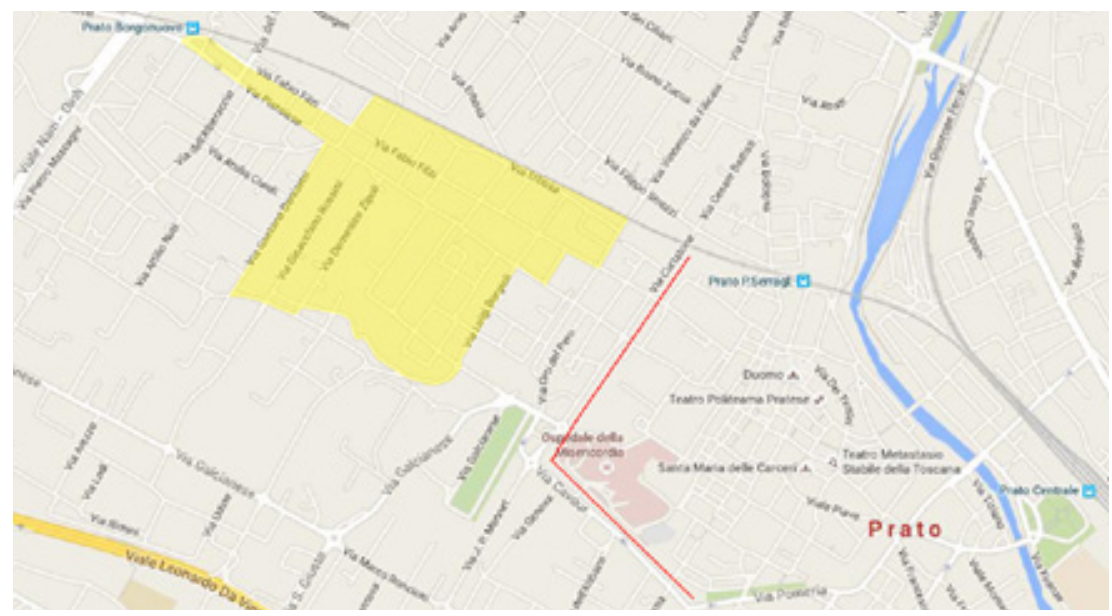

FIG. 3 The area highlighted in yellow corresponds roughly to 'Macrolotto 0'. The two red lines surround the old town centre. Processed by Google maps.

I have often heard, is that the 'Chinese live in Macrolotto' (Figure 3).

Sabrina Tosi Cambini and Massimo Bressan, described the 'Macrolotto 0 ' as a 'zone of transition', ${ }^{41}$ in which 'Il radicarsi della comunità cinese $[\ldots]$ è $\mathrm{da}$ rintracciarsi [...] nelle potenzialità spaziali e architettoniche di quest’area della città. La disponibilità di molti luoghi da riutilizzare; la capacità di comprendere questi spazi e reinterpretarli'. ${ }^{42}$

The high concentration of families from China-which now, in many cases, have children or grandchildren born in Italy-in a limited area makes for a unique mixture of different lifestyles, which are not always reconcilable. This includes varying approaches to daily life, work, relationships, housing, and management of public and private spaces.

By reflecting on the development of the space occupied by 'Macrolotto 0 ' and how Chinese relations within the area continue to change

41 Bressan and Tosi Cambini, 'The "Macrolotto 0"'.

42 Bressan and Tosi Cambini, 'Eterogeneità culturale', 218. My translation: 'The establishment of the Chinese community [...] derive from [...] the spatial and architectural potential of this area of the city. The availability of many places to be reused; the ability to understand these spaces and reinterpret them'. 
profoundly, we can understand the symbolic and physical struggle for the conquest or protection of space in a 'contentious' city like Prato. As Moreno pointed out in an interview, 'Take a ride... in some terraces in "via Pistoiese", there waves the Italian flag, as if to say, "we resist ... we defend the territory"”.

\section{$\operatorname{Ti}(\mathrm{e}) \mathrm{m}(\mathrm{pl}) \mathrm{e}$ and space}

According to the municipality estimates, in 2000, Prato had about 4,300 Chinese immigrants. Unofficial estimates accounted for twice this number. Some of these immigrants, the majority of them coming from Zhejiang 浙江, founded the Association 'ABC' ('Associazione buddista della comunità cinese'-'Buddhist Association of Chinese communities'), strongly characterized by its religious implications. ${ }^{43}$ These religious implications are the main reason this association differs from the 'Associazione d'Amicizia dei Cinesi di Prato' (Friendship Association of Chinese in Prato), founded earlier in 1998 with the intention of teaching Chinese language to second generation immigrants.

In those years, the majority of Chinese immigrants lived inside the 'Macrolotto 0', where the headquarters of the Association was located. The headquarters was situated at 'Via dei Gobbi', north of 'Via Filzi', before the railway which marked the northern limit of the so-called 'Chinatown'. After some time, as Antonio explains, the location was no longer considered appropriate and the headquarters was moved to 'via Filicaia'. In 2006, the group chaired by Jin Dezhong chose to transform the space, in both physical and symbolic terms, of the association into a temple, which became a meeting and cultic place. After deciding not to buy a farm in the Quarrata suburb, they were left with two options: a building at 'via Cavour' and a building at 'Pizza Gualchierina'. The final choice was 'Piazza Gualchierina', next to 'Piazza del Mercato Nuovo'. On July 17, 2007, the association

43 About the associations of Chinese abroad see for example: Wang, Le Nouvel An; Battiston, Dal Paese del Drago; Li, 'We need two worlds'; Yeh, 'In the Traditions'; Yeh, Making an American. 
purchased the property. On December 1 of the same year, a ceremony was organised to celebrate the placing of the first stone and, twenty days later, the first president renounced his presidency in favour of Huang Shulin, a wealthy businessman who could guarantee the success of the entire operation due to his personal ownings and network. On September 25, 2009, the temple was inaugurated in the presence of Prato's Episcopal Vicar, ${ }^{44}$ who also delivered a speech. The Association later changed its name to 'Associazione Buddista della comunità cinese in Italia' ('Buddhist Association of the Chinese community in Italy'), in an effort to become a reference point for all Buddhists of Chinese origin living in Italy (Figure 4). The connotations associated with the term 'temple' are restrictive and do not accurately describe the uses and prospects of the association. The building, in fact, is composed of many temples in a single structure ${ }^{45}$ and there are altars dedicated to both Buddhist and other popular religions, ${ }^{46}$ often associated with Taoist worship. ${ }^{47}$ There are also meeting spaces and a kitchen/dining hall where tables are used for teaching (Figure 5, Figure 6, Figure 7, Figure 8). As President Huang Shulin said on July 28,2014 , the Association's ambition is to transform the temple into a full-fledged monastery. For that reason, a major renovation is taking place, which includes a huge increase of the worship space and the construction of a comfortable accommodation for the monks.

The temple, in the state of 'durable provisional', ${ }^{48}$ is viewed as a controlled space where migrants are able to hold together the 'here'

\footnotetext{
44 Relations between the Catholic Church and the Association-Temple have remained constant over time. Just looking at yearbooks or at the notice boards inside the temple to see in the photographs a significant presence of members of the Catholic clergy during the recurring occasions: inaugurations, important festivals, public events. In particular, the good relations between the leaders of the Association-Temple and Monsignor Santino Brunetti (Episcopal Vicar for immigrants), have been repeatedly mentioned by Antonio, but also by Vittoria in their interviews.

45 Parbuono, 'L'Umbria'; Parbuono, 'Da Prato'.

46 Celli, Buddhismo; Masson and Istituto Ricci di Parigi e Taipei, Grandi religioni.

47 Bianchi, Taoismo.

48 Sayad, La double absence.
} 


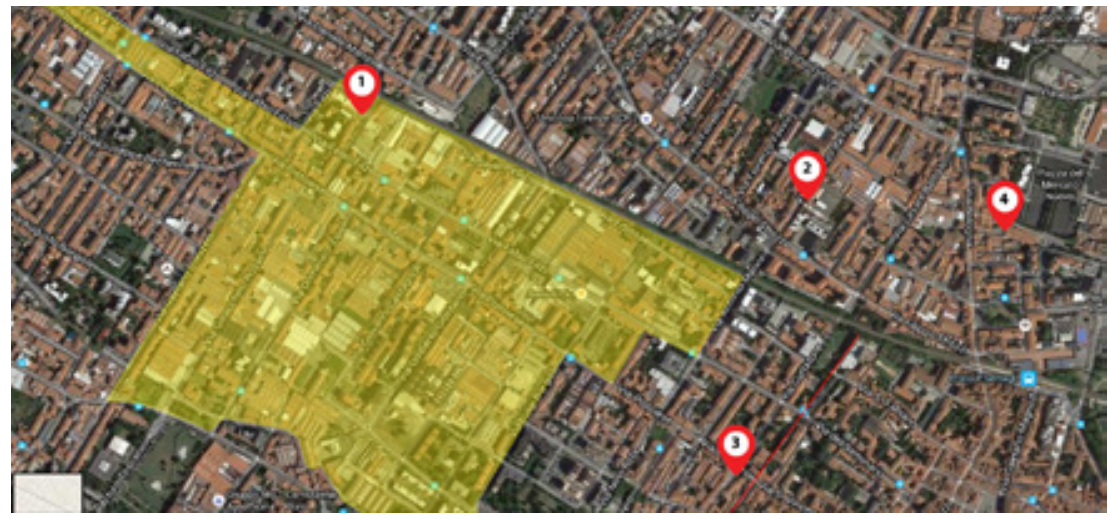

FIG. 4 Prato: 1. First headquarter of the Association: Via dei Gobbi 43; 2. Second headquarter of the Association: via Filicaia 14/a; 3. Possible headquarter of the Association-Temple: via Cavour 11; 4. Present headquarter of the Association-Temple: Piazza Gualchierina 19. The red line surround the old town centre. Processed by Google maps.
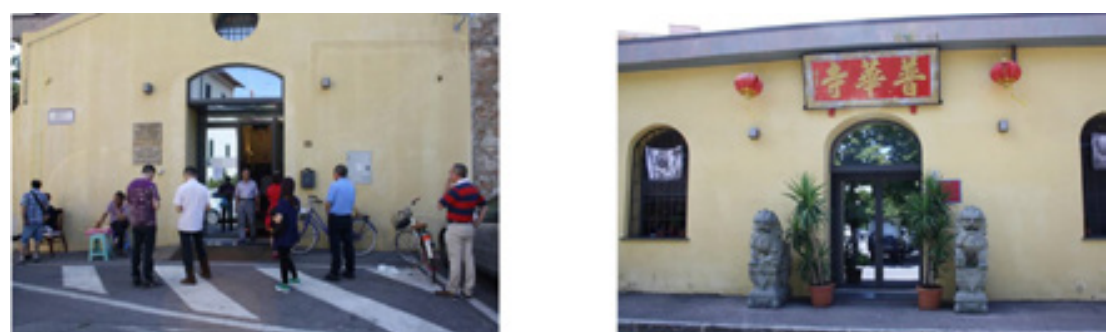

FIG. 5 The outdoor of the Temple. Photos by Daniele Parbuono, August 18, 2014 and July 27, 2014.
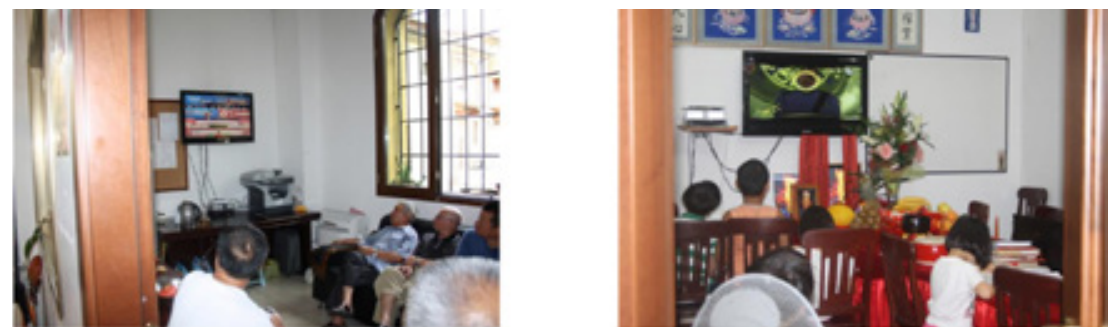

FIG. 6 Associational area. Photos by Daniele Parbuono, August 6, 2012. 

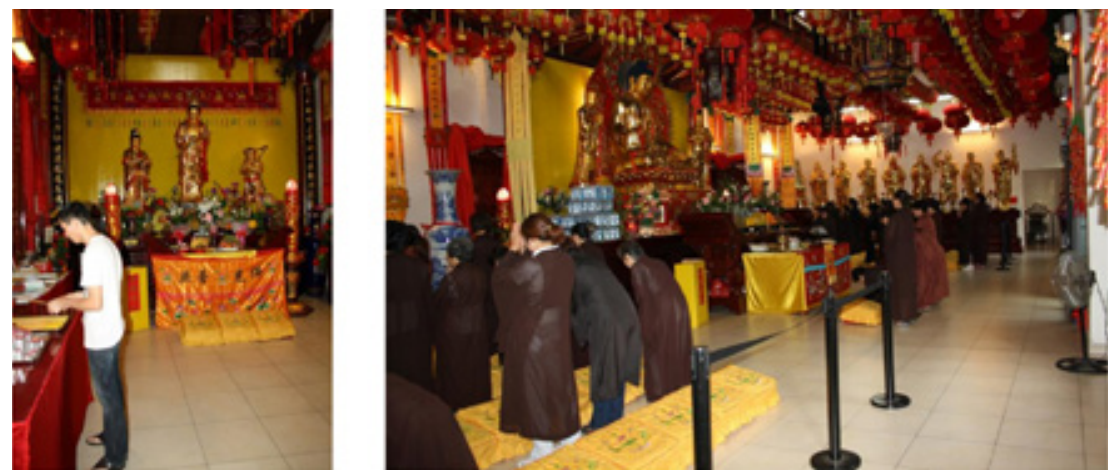

FIG. 7 Cultic area. Photos by Daniele Parbuono, August 6, 2012.
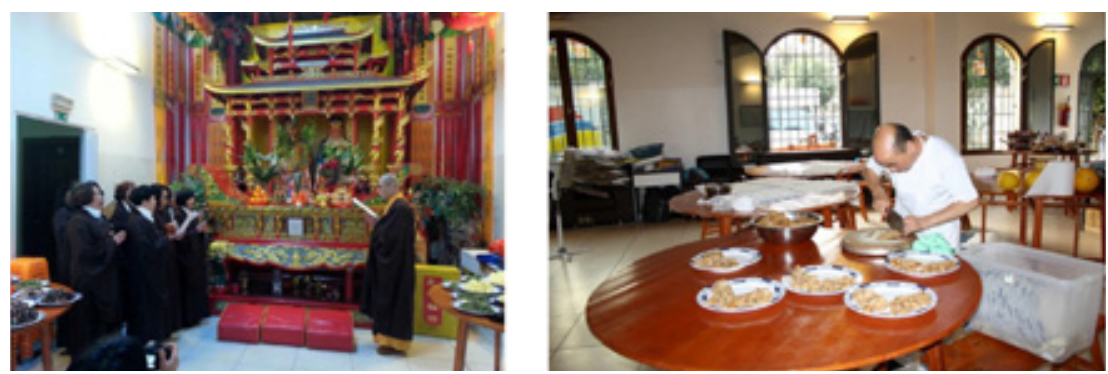

FIG. 8 Cultic area and kitchen-dining hall. Photos by Daniele Parbuono, December 22, 2014 and August 6, 2012.

and the 'there', the 'inside' and the 'outside', the 'self' and the complex context that surrounds them. Thanks to the temple, a number of redefined social ties that, as explained by Zai Liang talking about 'migration networks':

[...] connect migrants, former migrants, and nonmigrants in origin and destination areas through ties of kinship and shared community origin [...]. The availability of migrant networks increases the probability of migration by lowering the costs and raising the benefits of migration. Migration networks constitute a valuable social capital [...]. ${ }^{49}$

\footnotetext{
49 Liang, 'Demography of Illicit', 694.
} 
In addition, the temple assumed an undeniable centrality in the relationship between 'political' leaders of the part of the communities that attend activities offered by the temple, and the surrounding context. Moreno said, 'It has become some kind of reference point of the Chinese in Prato: if the Town Council needs to talk with some Chinese, they first call the temple'.

In more general terms, its location clearly represents the social tension that shapes the spatiality of Prato within a constant friction of positions and movements. In August 2013, after one of my meetings with Antonio, I noticed that the chosen location of the association's leadership was 'a matter of space'. Taking a look at the map of Prato, I would add that this 'matter of space' is not only about the building capacity, but also concerns the urban location of the temple as a nodal point of the city of Prato. This temple represents the Chinese community. For first-generation migrants, it is a gateway to the memory and a reunification of the living space left suspended elsewhere. For the second and third generations, it is a physical meeting point, as well as a point of knowledge, of study and of human and spiritual self-definition. The Chinese (or Sino-Italian or Italo-Chinese $)^{50}$ are reassured by the collective and political power of the temple. They strongly believe that the perception of this community as concrete and effective is a crucial element in enabling them to build relationships with the community outside of the temple as well. The urban location of the temple plays a symbolic role. Given the cooperative or conflictual anthropic organization of space, the symbolic dimension is undeniably central.

In the imagination of Prato inhabitants (but also of the Chinese, the Sino-Italian and the Italian-Chinese), the 'Macrolotto 0' (also called 'Chinatown') is a place of degradation. This location is stereotyped as the dirty stinky China, without rights and unacceptable human conditions. ${ }^{51}$ Italian flags were placed near signs stating,

50 It is difficult to define only as Chinese somebody who lived in Prato for thirty years or who (for example, children or grandchildren) has an Italian passport.

51 In a brief interview on December 19, 2015, Jack (43-year-old assistant to the Chairman Huang Shulin, Chinese, living in Prato), told me about the birth 


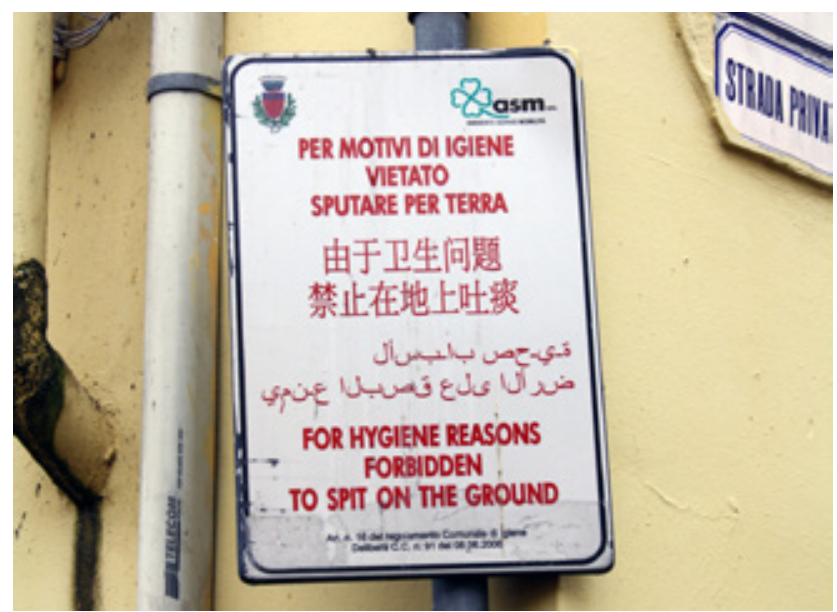

FIG. 9 Prato, 'Macrolotto 0’ area. Photo by Daniele Parbuono, March 1, 2015.

'spitting is forbidden', which were hung by the Town Council upon request of long-term Italian residents of the 'Macrolotto 0' neighbourhood (Figure 9). Despite this, recent projects aimed at a peaceful coexistence were promoted with the help of some local associations. $^{52}$

The peregrinations that led to the choice of 'Piazza Gualchierina' started in the early twenty-first century. During those years, a bitter social conflict arose because of the complexity of the migration issues. First, in 2007, the Chinese New Year parade was denied permission to pass through the 'Piazza del Comune' ('Town Square').

of a new association, the 'Città del Cervo Bianco' ('City of White Deer'), a name coined by the nickname of Wenzhou 溫州, in Zhejiang, the city of origin of most Chinese migrants. Jack explains that this Association-whose leaders are linked to the Temple, in fact, he is the Secretary, and Mary (Vice-President of the Association-Temple) is the President-was born with the aim of promoting the integration and that the first goal to be achieved, as evidenced by the articles published in the local press, is to solve the problem of dirt in the 'Macrolotto 0'. (http://www.tvprato.it/2015/12/la-citta-del-cervo-bianco-concede-il-bis-nuovapulizia-in-via-pistoiese, consulted on January 1, 2017).

52 Baldassar, Johanson, McAuliffe and Bressan, Chinese Migration. 
Two years later, in 2009, in the 'red Prato',53 a conservative, rightwing candidate won the mayoral elections for the first time.

The political climate of that time is evident by observing the locations of the different headquarters of the Association-Temple on a map. The first headquarters, located within 'Macrolotto 0', was identified at the end of the 1990s, before public debate reached the extreme tone it manifested at the beginning of the millennium. The presence of the headquarters in 'Macrolotto 0' possibly held a specific political meaning. Its position was at the centre of a 'mobile community' that, at least at the beginning, defended itself, was self-determining, and looked inward, rather than outward, for subsistence.

As conditions shifted, the association (which later became the temple) needed to symbolically extract its 'Chinese image' and promote social, economic and industrial interchanges with other inhabitants of Prato, Tuscany, and Italy in general. The Association 'ABC' later became 'ABC in Italy', changed seat. First of all, it was moved near the 'Macrolotto 0' area but not inside, then it was moved near the old town centre area-although many residents of the area were foreigners, the town Council headquarters was there, and it was perceived as an Italian stronghold-but not inside. It finally found its right place, as the result of a convincing cultural arrangement: 'Piazza Gualchierina', near both the 'Macrolotto 0' and the old town centre, but not directly inside of either boundary. The placement of the temple is politically strategic: it is near to the Chinese, as well as the Italians, but it never definitively identifies with one or the other. This illustrates the cultural reality of the thick Sino-Italian migration in Prato.

\section{The Chinese New Year, Chunjie 春節}

Throughout the year, the temple attracts, condenses, and catalyses immigration forces and needs. This movement within the temple

53 It means that many people are linked with the history of the Italian political left: the Communist party and its contemporary evolutions. 
reflects the complex reality of Chinese migrants and can be easily observed by anyone who enters the space. The temple functions as the 'parlour' where Sino-Prato stakeholders can present their ideas for peaceful coexistence and reassure themselves, as well as all the people who might be useful for the social, economic, and industrial aspects of coexistence. Italian leaders of associations, professional politicians, prominent members of the Catholic Church, and higher ranks of the police force are always present during important rituals, such as the ritual collective consumption of food.

The 'organisational machinery' and socio-economic potential of the temple association is often the incentive for this heterogeneous group of migrants to come together and develop professional, political and friendly relationships that are constantly crossing boundaries and being redefined. Under the glaring eye of the media, the temple often creates collaborative philanthropic projects. For example, they donated money to victims of an earthquake disaster, gave aid and equipment to Italian humanitarian associations, and donated clothes to be distributed by the chaplain of a local prison. Additionally, individual members of the temple often make donations to support local initiatives.

The truly enormous power of the temple is revealed during holidays, when the Association organizes events. The negotiations between internal cohesion and the complex relationship with the outside community is important during this time. The yearly calendar of events displayed at the spring festival (Chunjie 春節), or Lunar New Year (nongli Xinnian 農曆新年), better known in Italy as the Chinese New Year, is a clear example.

For many years, the anthropological debate has carefully explored the political dimensions of the festival. ${ }^{54}$ It is during 'controlled' festive times that the temple association emphasizes the socio-cultural importance of its diverse Chinese groups. They not only consolidate the strength of internal relations, but also look to expand their net-

54 See, for example, Apolito, Il tramonto; Ariño \& Lombardi Satriani, L'utopia; Bonato, Festa viva. Continuità; Bonato, Festa viva. Tradizione; Mugnaini, Feste, luoghi; Palumbo, Politiche; Parbuono, 'Storie' e Feste. 
work by creating ties with outside parties that contain prestige or power in the surrounding urban space. ${ }^{55}$

The Lunar New Year festivity is an occasion to bring together the old and the new, the arrivals and departures, the places of origin and places of residence, and to rebuild people's perspectives. Paolo Apolito pointed out, 'Essa implica [...] un vissuto comune degli attori che appartiene al livello delle emozioni e dei sentimenti [...] ${ }^{56}$ In this case, there are different experiences to keep in mind. Gioia told us that it is difficult to start friendships with Italian guys. In 2015, she participated in the Chinese New Year because for a short, 'liminal' time the struggle of cultural separation seemed less prevalent: 'I dressed up as a boat... it's a pleasant thing, and so I can get to know many more friends. During the Chinese New Year people feel close... even Italians'. ${ }^{57}$ In addition to the increase of intercultural friendship networks, there is a feeling of reassurance among participants. Although the organizational phase is characterized by frequent friction and conflicting positions, the aesthetics during the festival create a temporary suspension of all these tensions. As Jing Wang wrote about the Chinese New Year in Paris:

Comme dans toute cérémonie de cette taille, des tensions peuvent apparaître, aussitôt calmées au nom du discours général qui enveloppe cette fête et la présente partout comme un moment d'harmonie où toutes les disputes s'apaisent, où toutes les frictions sont immédiatement résolues, où tout est partage. ${ }^{58}$

55 For an overview of the studies on 'social networks' see Piselli, Reti. The concept was developed by researchers of the 'Manchester School'; for a summary of these works see Arrighi and Passerini, La politica.

56 Apolito, Il tramonto, 11. My translation: 'It implies [...] a common experience of the actors belonging to the level of emotions and feelings [...]'.

57 Gioia (19-year-old high school student, born in Wenzhou, living in Prato for seven years), in discussion with the author. December 19, 2015.

58 Wang, 'Le Nouvel An', 177. My translation: 'As in any ceremony of this kind, the tensions may appear immediately calmed in the name of the general discourse which concern this festival, and presents it everywhere as a moment 
Similarly, Giulia explained:59

[...] Everybody has fun, meaning that are integrated, because when they pass in 'via Pistoiese' you see that everybody is there... you can enjoy the same atmosphere. That is, in that moment we are all compact, there are not so many differences [...] Chinese guys and Italian guys at that time... what gives me the feeling is that we are all equal, no rivalry between who is Chinese and who is Italian.

Those who lived in China long before arriving in Italy feel homesick. They want to feel in contact with the aspects of life and family that remain far away from them, especially during these important days of the year. As Maggi Leung explained:

[...] the rousing of homing desire is particularly noticeable prior to important Chinese festivals. Advertisements in the newspapers and on the Internet reminding readers of the coming of Chinese New Year or Mid-Autumn Festival—-these are two special occasions when (transnationalized or translocalized) families get together. ${ }^{60}$

For those with institutional responsibilities inside the temple, which function as political roles, a public event as extensive as the Chinese New Year is an important opportunity to build relationships and negotiate subjective and collective hegemonic positions. ${ }^{61}$

In much of the research on Chinese migration, ${ }^{62}$ the subject of Chinese New Year is often heavily studied and observed. Regardless of their differing approaches and objectives, each scholar recognizes

of harmony in which all conflicts subside, where all frictions are immediately resolved, where everything is shared'.

59 Julia (19-year-old high school student, born in Prato to Chinese parents, living in Prato), in discussion with the author. December 19, 2015.

60 Leung, 'Rethinking "Home”, 226.

61 Faeta, La festa.

62 It is worth mentioning the works of Auguin ('Le Nouvel An') and Jing Wang ('Le Nouvel An') about Paris, the most dated Monica E. Vickery (Chinese 
the strong connection between the organization and management of festival dynamics with the context of migration, despite varying economic and political situations. In line with previous research written on this topic, the systematic debate tends to view the Chinese New Year in a migration context less as an impromptu masquerade exclusively aimed at enjoyment or the honouring of an important holiday, but rather as a performative tool for gaining space in the public arena. This understanding of the strategic importance for the Chinese is confirmed by the involvement of the Chinese government. They not only grant high authority to this holiday but have also attempted to 'manage' it on several occasions. Chang-Tai Hung's study is significant to this point. His study explained that since 1949 , the government has repeatedly tried, with poor results, to use nianbua 年畫, traditional Chinese New Year decorative paints, as a propaganda tool by replacing the mythical-religious subjects with State images. ${ }^{63}$

New Year) about London and those of Chiou-Ling Yeh ('In the Traditions of China; Making an American') about San Francisco. Apart from these, the thesis of Ilaria Battiston (Dal Paese del Drago) on the Lyon new year and the volume of Li Minghuan ('We need two worlds') on Chinese associations in the Netherlands. The Chinese New Year in the great European capitals, as well as that of San Francisco-cities affected by Chinese migratory flows different in quantity and durability - for impact and number of events, are not easily comparable with the most recent and slight festival of Prato. My ethnography on the festival still on-going lets me think that both the Association-Temple leaders, both local institutions (Municipality administration in particular) are trying to gather ideas and to gradually extend programs basing them on more established and structured examples. As it happens in Paris, London or San Francisco (to refer some of the most known), in 2016 Prato's Chinese New Year calendar, the leaders of the Association-Temple have included conferences (like one on Buddhism held by my colleague Ester Bianchi) and public religious rituals (the most significant, during the public parade, right in 'Piazza del Comune'), while local associations and Municipality administration sustained a dense program of events from February 19 to February 21 (http://www.pratosfera.com/2016/02/04/capodanno-cinese-2016-prato-programma/, consulted on January 11, 2017).

${ }^{63}$ Hung, 'Repainting China'. 
As mentioned above, the Chinese New Year in Prato is organized by the Association-Temple. Andrea and Vittoria reminded us of the time of the restricted editions since the early twenty-first century. In an interview, Vittoria asserted, 'they did it between them alone in the industrial zone'. To further illustrate these celebrations, we will take the 2015 edition as an example. The calendar of planned events can be divided into four main phases. The first phase is the preparation. After the summer, as explained by Mary, ${ }^{64}$ the temple association leaders began to plan the details of the program, choose the itinerary and, most importantly, commenced 'spreading the word' so that volunteers could be informed. The staff of the President are in charge of management. Their duties included selecting institutional partnerships, giving out the official invitations, and, especially essential, requesting the necessary regulatory approvals. A selected group of volunteers rehearsed the choreography of the parade each week. 'All the materials are properties of the temple, the costumes, the dragon... then we must prepare them and make rehearsals' ${ }^{65}$

The second phase is made up of social occasions. ${ }^{66}$ In the 2015 edition, in addition to the usual meals eaten inside the temple, a special gala dinner focused on economic and trade issues was organizedthough not directly by the Buddhist Association-for five hundred Chinese entrepreneurs from all over Italy and abroad.

A radunarli [...] nella simbolica Prato, l'Associazione per la promozione del commercio sino-italiano, che ha sede a Milano ed è presieduta da Massimo Ye Zhonghe. Invitati anche i rappresentanti delle istituzioni pratesi [...]. Lo stesso Ye Zhonghe ha spiegato che il

64 Mary (44-year-old businesswoman in the ready-to-wear fashion industry, Vice President of the Association-Temple, Chinese, living in Italy since 1993), in discussion with the author. December 19, 2015.

65 Mary, December 19, 2015.

66 The Chinese New Year lunches begin earlier than February. In January 2015 some members of the City Council were invited to have lunch in the Temple with the intention to get support in the organization of the parade ( Il Tirreno Prato, 'Sfilata del Dragone'). 
pranzo è stato organizzato per avviare un dialogo con la comunità cinese di Prato e soprattutto con le istituzioni italiane nella prospettiva di avviare scambi commerciali. ${ }^{67}$

The large-scale media coverage on Chinese New Year, along with spectacular manifestations, is used to settle commercial alliances, study new possibilities of action, and enter in the public space through the network of political and economic relations that come by the temple, including its initiatives and those associated: 'Pendant les deux semaines que durent les festivités, une série de manifestations obligées renouvellent l'alliance entre les "Asiatiques", présentés et pensés alors comme une "communauté", et les pouvoirs politiques locaux et nationaux'.68

The third phase is the bell tolling ceremony held inside the temple at (Chinese) midnight of the New Year (Figure 10):

Before the bell sounds, the two guest monks officiate a Buddhist ritual [...] Around 4 PM people begin to arrive, including members of the law enforcement and volunteers of the Red Cross. At 4.30 PM those present in the main hall are led out and, under the guidance of Anna, the new secretary of the Association, some volunteers prepare the space for the bell tolling. The internal order is crucial; everyone would like to ring the bell before the others to obtain more luck: the bell is a good omen for the new year. Meanwhile, at the entrance of

${ }^{67}$ Aragoste e vini pregiati per il Capodanno dei vip cinesi, Il Tirreno Prato, February 1, 2015. My translation: 'To gather them [...] in the symbolic Prato, the Association for the promotion of Sino-Italian trade, which is based in Milan and is chaired by Massimo Ye Zhonghe. Are invited representatives of Prato institutions [...]. The same Ye Zhonghe explained that lunch was organized to start a dialogue with the Chinese community in Prato and especially with the Italian institutions to open trade'.

68 Wang, 'Le Nouvel An', 185. My translation: 'During the two weeks of the festivities, a series of obligatory demonstrations renew the alliance between the "Asians"- presented and thought at the time as a "community" - and the local and national political powers'. 


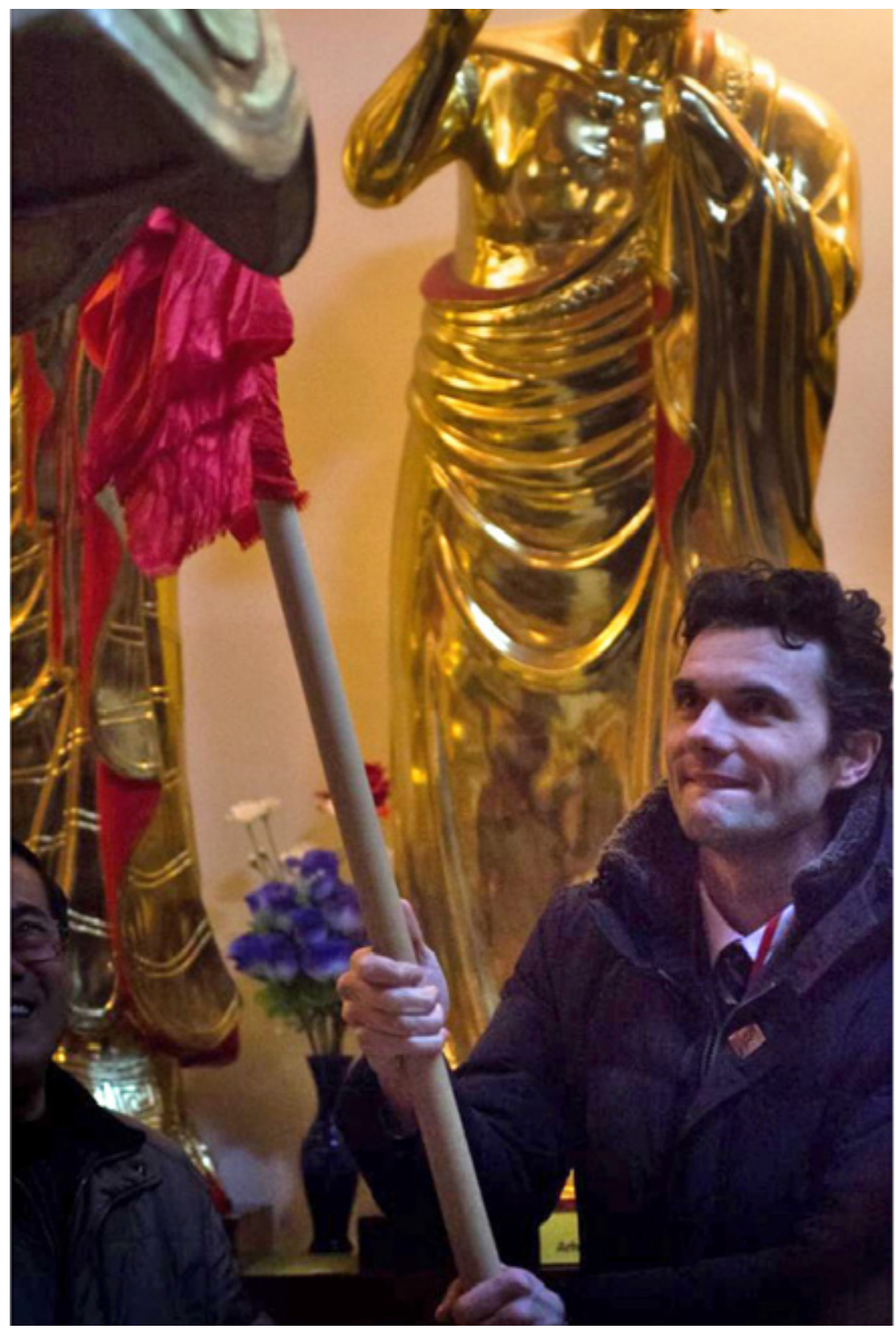

FIG. 10 The mayor of Prato Matteo Biffoni ringing the bell. Photo by Elisa Dainelli, February 18, 2015. 
the Temple two members of the Association have created a barrier with ropes to hold the large mass of people. Behind them Anna, the real event director, decides who can enter. When the mayor and one of the councillors arrive, she makes space for them and welcome them warmly. Near the entrance, each person takes a badge and with it everybody receives a red envelope which then will serve for the cash offer. Here come the guests of honour that, of course, jump the line: high degree of law enforcement, distinguished members of the Church, politicians and representatives of associations. A row in front of the bell is created: the first to ring the bell is one of the guest monks who at 5 PM rings it three times. Anna manages the line following a hierarchy that places Westerners in a privileged position. At first the hosts, that is, the monk and the Chinese authorities. After them, western political-religious authorities, followed by all other Western, then the lay Chinese followed by all other Chinese. After having ring three times the bell, each one inserts the envelope with the money in a box guarded by a keeper (Diary, February 2, 2015).

This phase is an important moment between the temple and the city. The doors are open and hundreds of people-both Chinese and non-Chinese-line up to ring the bell to gain 'good fortune'. The occasion is wisely utilized by the temple managers to let people in to explore and to give an air of openness, welcoming, and willingness to accept all. People of Prato can ritually enter the ceremonial centre of the temple, which, as mentioned, is directly in between the primarily Chinese populated 'Chinatown' and the primarily non-Chinese populated old town centre. With the shuffling together of all these different people, the inside of the temple symbolically becomes 'another Prato'. In this symbolic Prato, the Chinese are included and maintain a stronghold concerning the number of people, as well as their economic, industrial and political power. However, in the areas where this symbolic 'Prato' short circuit, a heterotopia dimension is produced. ${ }^{69}$ This heterotopia creates a place where the concepts of administrative boundaries, geographic limits, and

69 Foucault, Utopie eterotopie; Foucault, Eterotopia. 
'centre' have completely different meanings. 'Cependant, l'essentiel du Nouvel An chinois public ne réside pas dans la mise en scène de l'identité culturelle. Ces festivités sont, de fait, le lieu d'enjeux bien plus fondamentaux pour la communauté chinoise'. ${ }^{70}$ Currently, the temple is in the decentralized centre-not surprisingly it is in a neutral zone (near but not on the inside). It operates as a meeting space, the essence of the new urban dimension. This new centre is becoming a symbol for the 'transition' that citizens of Prato undergoing. The citizens' power and contemporary global socio-economic history intersect and intertwine, bringing a new meaning to the way of life in Prato.

Finally, the fourth phase is about the parades, which are usually organized ten days after the bell tolling ceremony. About one hundred and fifty people dress up in 'traditional' run through the streets of the city, accompanied by the bursting of firecrackers and the sounds of drums. Throughout the parade, there are many people who wear masks made in Italy that, as Haiyou explained, bring good luck. ${ }^{72}$ Some of the iconography on these masks include boats and fish (Figure 11). The parade is also composed of girls carrying lanterns and groups of people wearing imitations of 'ethnic minorities traditional dress': the shaoshu minzu 少數民族 (the Chinese government recognizes fifty-six of them). The parade also consists of women dressed in red, marching and hitting small drums; boys dressed in red or green (Italian and Chinese) carrying national flags and temple pennants; and men wearing tunics and plastic masks representing Buddhist, Taoist and folk religious figures.

70 Auguin, Le Nouvel An, 76. My translation: 'However, the focus of public Chinese New Year does not consist in the staging of cultural identity. These festivities are, in fact, the space for much more fundamental issues for the Chinese community'.

71 About the problematic nature of the concept of tradition I refer to Palumbo, Politiche and Clemente and Mugnaini, 'Oltre il folklore'.

72 Haiyou (55-year-old, one of the Association-Temple leaders, Chinese, living in Prato), in discussion with the author, December 19, 2015. 

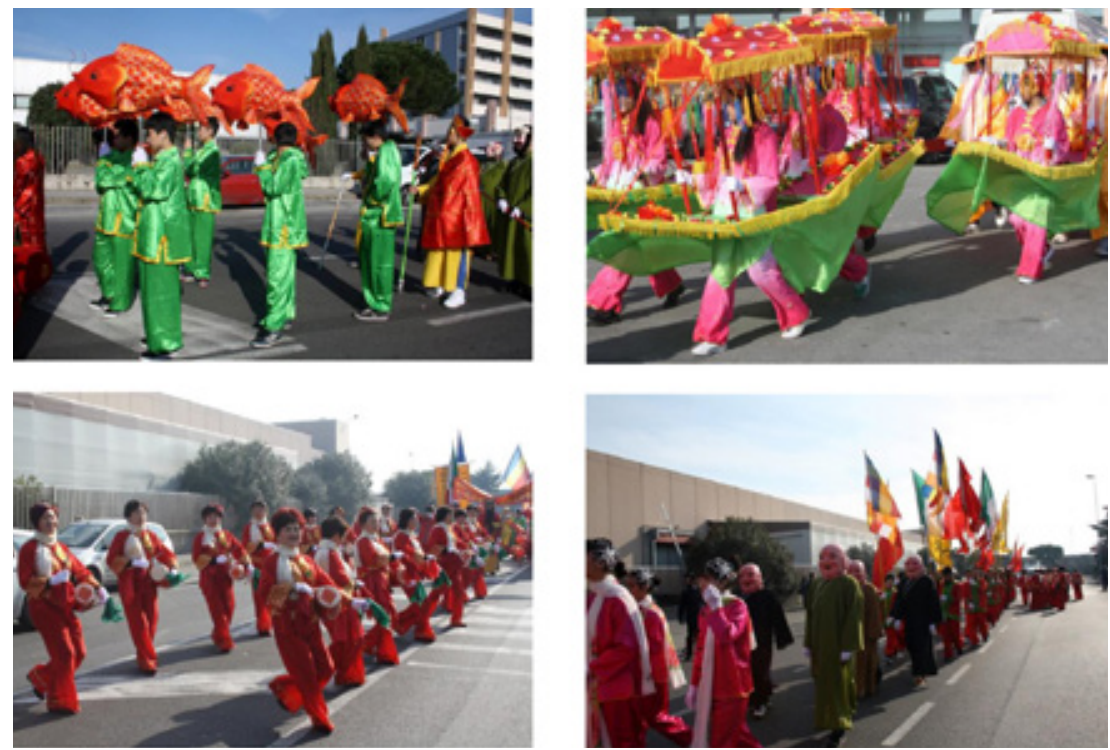

FIG. 11 Start of the parade in the industrial zone. Photos by Daniele Parbuono, February 28, 2015.

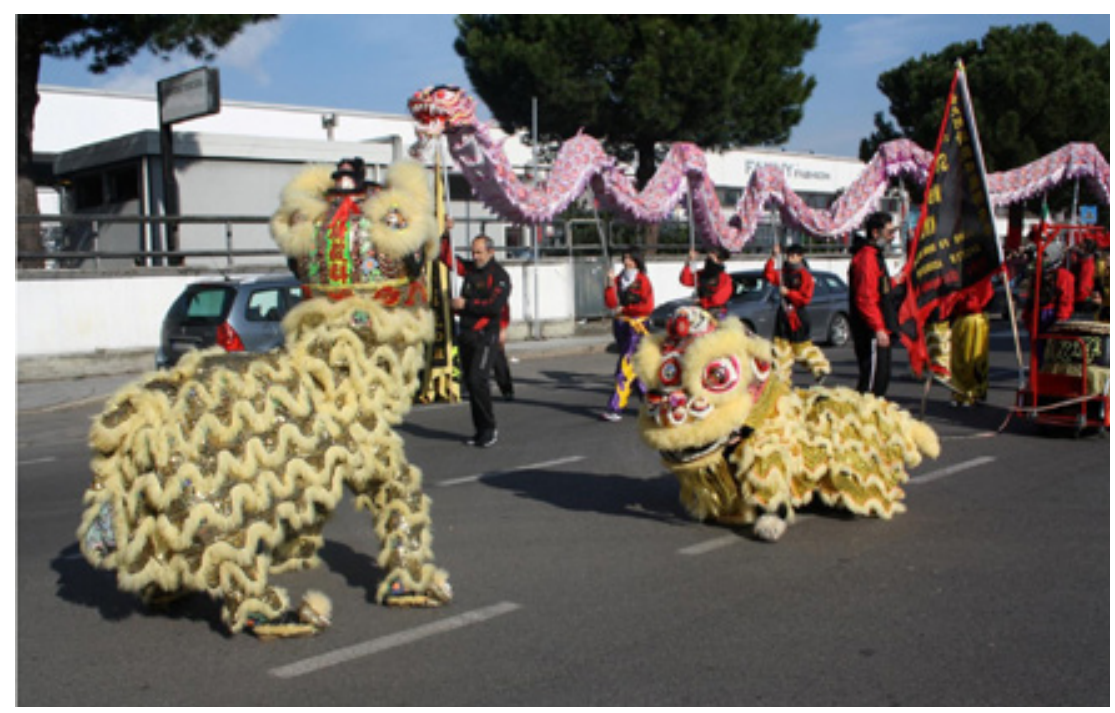

FIG. 12 Dragon and lion of 'Italy Lion and Dragon Dance'. Photo by Daniele Parbuono, February 28, 2015. 

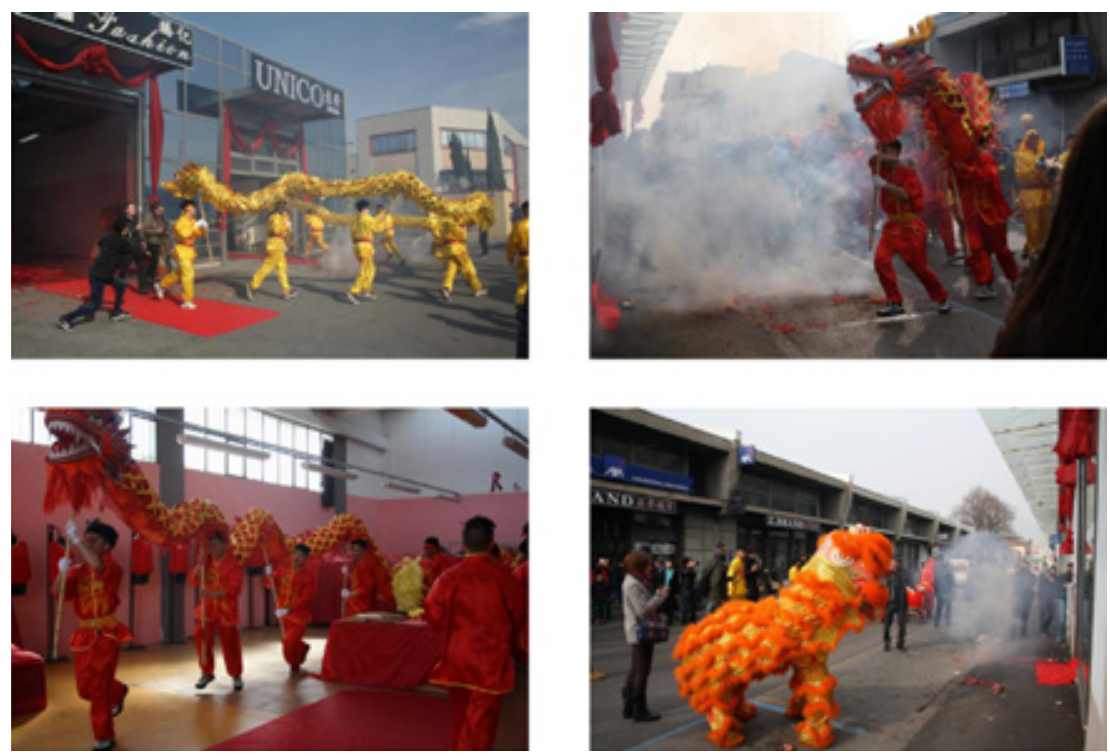

FIG. 13 Dragon and lion of Buddhist Association bring 'luck' inside the factories; Photos by Daniele Parbuono, February 28, 2015.

At the heart of the parade there are dragon and lion masks (Figure 12, Figure 13). The dragon is a powerful mythological figure who controls the forces of heaven and earth. ${ }^{73}$ The lion, on the other hand, directly refers to the founding myth of the Chinese New Year. Legend has it that in China, before historical time, there lived a beast named Nian (年 in Chinese it means 'year') and on a specific day of the year it came out of hiding to eat men. The only way to avoid this carnage was to scare him with loud noises and red drapes, hence the predominance of red colour and firecrackers in the Chinese New Year. In the parade, the dragon mask is carried by about ten boys. They run in and out of factories or shops, ready to receive the procession and bring luck in business in exchange for offerings. After the visit of the dragon, all participants, including the audience, can enjoy free food prepared by the owners of the above-mentioned factories or shops (Figure 14). The lion mask (there can either be one or many) is

73 An and Yang, Handbook. 


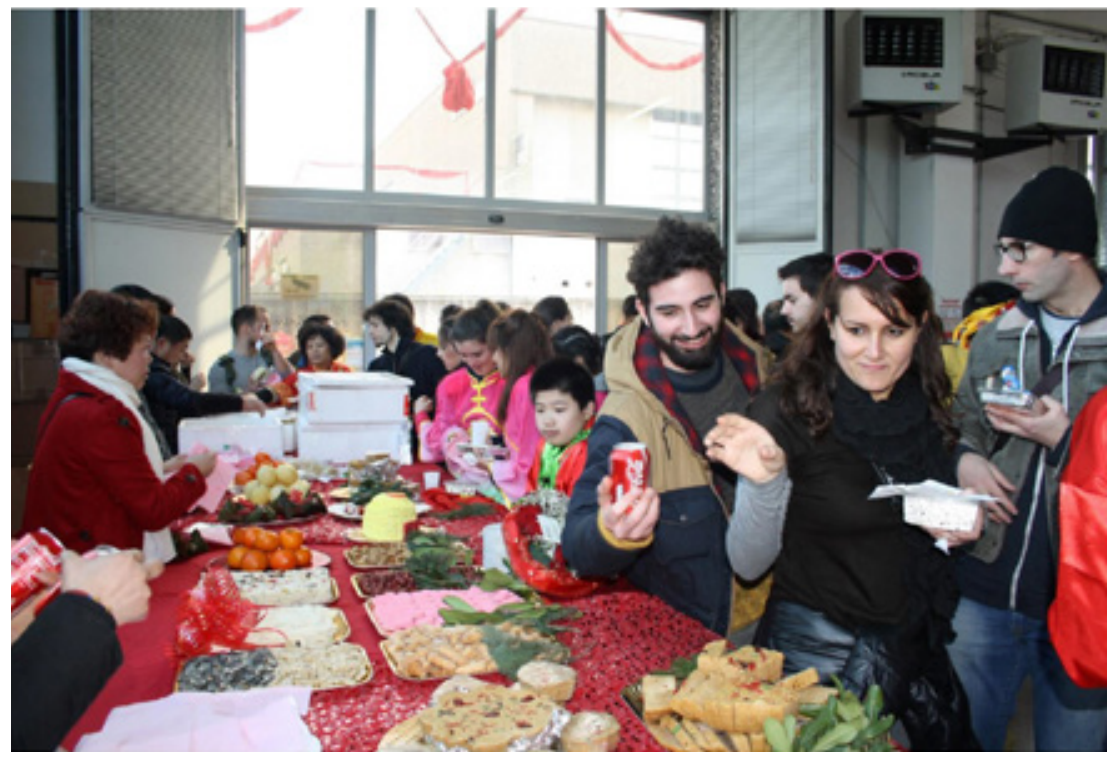

FIG. 14 Common luncheon inside a warehouse in the industrial zone. Photo by Daniele Parbuono, February 28, 2015.

worn by two athletic built boys who usually stop in the more densely crowded areas to perform the famous 'lion dance'. While explaining the reasons behind the dance, Giampaolo provided us with a more detailed version of the original myth: ${ }^{74}$

Giampaolo: one of the most reliable legends says that this monster was looting in the villages, however, when farmers began to realize that he actually ate only the salad and that this brought good luck, wealth and prosperity, they began to treat him as a sacred beast... when he came out, then they offered him the salad. But... the story is mixed with the myth; salad in China is cài $i$ 菜... that read in a different tone ( $\left(a^{\prime} i\right.$ 財) means money, so the salad is a symbol of wealth... the lion eats the wealth and donates it back. Parbuono: so, the dance is performed to gain wealth and money? Giampaolo: yes, correct.

74 Giampaolo (39-year-old master of 'Italy Lion and Dragon Dance', Italian, living in Perugia), in discussion with the author, Perugia, December 17, 2015. 
Giampaolo is one of the peculiarities of the parade. He is a director at an Italian school of dancing in Perugia, with non-Chinese pupils, where the lion and dragon dances are taught. In 2015, the temple association leaders invited his pupils to the Chinese New Year parade and offered them a starring role. The association maintained the staging of the lion and dragon masks that enter into factories and shops, but they asked Giampaolo's Italian school of dance to perform the starting dance of the parade that occurs when the procession leaves the temple. Giampaolo justified his invitation by saying that 'this is due to the fact that I am an acknowledged dancing master, they do not have dancing masters'. The 'Sbandieratori e Musici della Signoria di Firenze' (a historical group of flag bearers and musicians from Florence) have also been invited to perform at this event before. The active involvement of Italian groups in setting up this event, coupled with Vittoria's explanation that 'some years ago Antonio started to invite Italian associations and groups; he felt it was important', seems to support Chiou-Ling Yeh's hypothesis. His hypothesis emphasized the existence of a supposed Italo-Chinese 'cultural compatibility' as an attempt to legitimize the presence of the Chinese in the public dimension; to reassure the citizens of Prato by creating an indistinct and shared universe; ${ }^{75}$ and to claim greater 'spatial justice. ${ }^{76}$

The greater problem to deal with is the itineraries. Three parades were organized for the 2015 celebration. The first one was performed in the industrial area on February 28. The second one was performed in the central areas, starting from the temple, on the morning of March 1. The third was performed in Seano (hamlet of Carmignano), where many Chinese have chosen to live, during the afternoon of March 1.

75 In the interview of December 19, 2015, to my question, 'ma perché invitate al capodanno anche "gruppi storici" italiani come i Musici della Signoria di Firenze?', ('but why do you also invited to the New Year historical groups such as the Musici della Signoria di Firenze?'), Haiyou replied 'amicizia, amicizia, amicizia... siamo tutti uguali no!?’. ('friendship, friendship, friendship ... we are all equal no!?').

76 Yeh, 'Making an American Festival'. 
The path of the second parade highlights three important issues: urban spaces were shaped as the result of socio-economic, thus political, dynamics; the temple is a religious referent endowed with political power; and, lastly, behind the apparent folkloristic dimension of the Chinese New Year, decisive political games are played for the negotiation to obtain public spaces.

\section{Conclusion}

During the Chinese New Year, the groups composing the Chinese community in Prato have the opportunity to show off their 'presence' and power. This is a moment of 'hypervisibility', ${ }^{77}$ in which, at a particular stage of the relationship between being 'Chinese' and the arriving context, those migrants who 'filled the void', '[...] engaged in the process of manipulating urban spaces [and] are accused of surpassing the "upper threshold of correct visibility". ${ }^{78}$

At the beginning of 2007, the public debate grew tense due to increased immigration, especially of Chinese immigrants. The majority of the Chinese previously lived in 'Macrolotto 0', but the wealthiest ones moved to other areas of the city. Andrea commented, 'now they live in many other areas, a bit everywhere'. The association's leaders worked hard to establish a temple in a location outside of the space that the public imagination felt was 'occupied' by the Chinese, in Piazza Gualchierina. The New Year's events are becoming a 'new tradition' in the calendar of Prato's feasts. At first the temple was simply a meeting spot for a few people, but as its functions grew, participation and public attention increased. In comparison to the earlier years, something got stuck in the parades' organization and the itinerary had to be changed. The City Council, guided by the centre-left party, denied them permission to access the old town centre, which forced the organizers to hold the parade in the Amphitheatre of the Pecci Museum. The choice

\footnotetext{
77 Brighenti, Visibility.

78 Cancellieri and Ostanel, 'The Struggle', 500.
} 
of location did not seem fortunate. The art workshop 'Senza dimora fissa' - tied to 'Dryphoto' Association, which sometimes helped to organize the Chinese New Year-wrote in a press release: 'Un luogo inaccessibile alla vista, chiuso, che è una fortezza racchiusa tra la questura, il tribunale, la caserma della guardia di finanza e quella dei carabinieri'. ${ }^{79}$ The City Council, aware of the tension among the people, explained the reason for the permission's denial by saying that 'il clima in città non lo permetteva' (ibidem). ${ }^{80}$ The New Year's events were considered under control and the parade, functioning as a symbol for the Chinese expansion, was contained in a reassuring framework of meaning.

There were also many people opposed to the Town Council's decision. In the meantime, the Association's leaders (while the temple was being built) used their relationship network to quickly find a solution and regain space. Many associations shared their networks with those of the Association-Temple, the leader of the Italian associations being 'Dryphoto'.

After the 2007 Chinese New Year, a long negotiation began, where the temple association asked 'Dryphoto' to mediate the conflict between themselves and the Town Council. Things remained complicated. As Vittoria explained, 'there still were protests of many Prato citizens who did not want the Chinese New Year', but in the end, in the 2008 edition, the parties agreed to symbolically more open and meaningful behaviour. The Town Council granted the Association to hold the Chinese New Year celebrations in the streets of the industrial zone, those of the 'Macrolotto 0', 'Piazza San Domenico' ('San Domenico Square'), just inside the walls of the old town centre at the end of 'Via San Vincenzo', and the extension of 'via Pistoiese', main street of the so-called 'Chinatown'. This tug of war for the conquest of space was clearly ongoing. The

79 Undo.net, 'Capodanno cinese' [Chinese New Year]. http://1995-2015. undo.net/it/evento/48201\#; consulted on January 1, 2017. My translation: 'A place inaccessible to the eye, closed, which is a fortress enclosed among the Police, the Court, the barracks of the Financial Police and of the Carabineers'.

80 My translation: 'the climate in the city did not allow it'. 
temple's leaders tried to get out of the 'Macrolotto 0' that they perceived as a kind of a ghetto. They tried to earn space and get involved in the daily life of the city. They built the temple in an area nearby, but not on the inside. They organized Chinese New Year celebrations and hoped that Italian and Chinese 'traditions' could interact and coexist. Through the parade, they symbolically asked to enter in the heart of what many migrants felt to be their city. However, in 2009, the struggle to obtain more space became a delicate political matter when the centre-right, conservative party won the mayoral elections and Italian flags were hung outside numerous balconies in 'Macrolotto 0'. Restrictions were set on how far the parade was allowed to go. 'Piazza San Domenico' ('San Domenico Square') was the extreme outer limit for the parade. 'Piazza del Comune' ('Town Square'), in the centre of the city, and two hundred and fifty meters after Piazza San Domenica remained off-limits for another six years.

In 2015, when the centre-left party was back in power, dragons and lions could again dance in front of the City Hall. 'It depends on the Mayor', Haiyou said. The fact that the Chinese New Year reobtained permission to enter 'Piazza del Comune' ('Town Square') was dependent on a general climate of relaxing of tensions. The 'political' presence of the temple helped to improve this urban coexistence. Many questions still remain unaddressed, including human rights, working conditions in the factories, the underground economy, and the urban décor. In the meantime, the most critical area, 'Macrolotto 0', is being redefined as a metaphor for a peaceful coexistence thanks to integration projects and attempts to requalify space. The Chinese New Year parade that starts from the temple, passes through the 'Macrolotto 0' and greets 'Piazza del Comune' ('Town Square'), undeniably shows the outcome of a long history of urban encounters (Figure 15). Prato faced great changes due to an internal migration after the war and international immigrations around the 1990s, but it is moving toward a promising future of fast growth, stronger connections and closer proximity. The conflict, at least at this stage, seems to have given space to form an inevitable tolerance. 'In turn, tolerance is not an aspect of diversity, but the extent to which people embrace diversity. To be tolerant does not require 

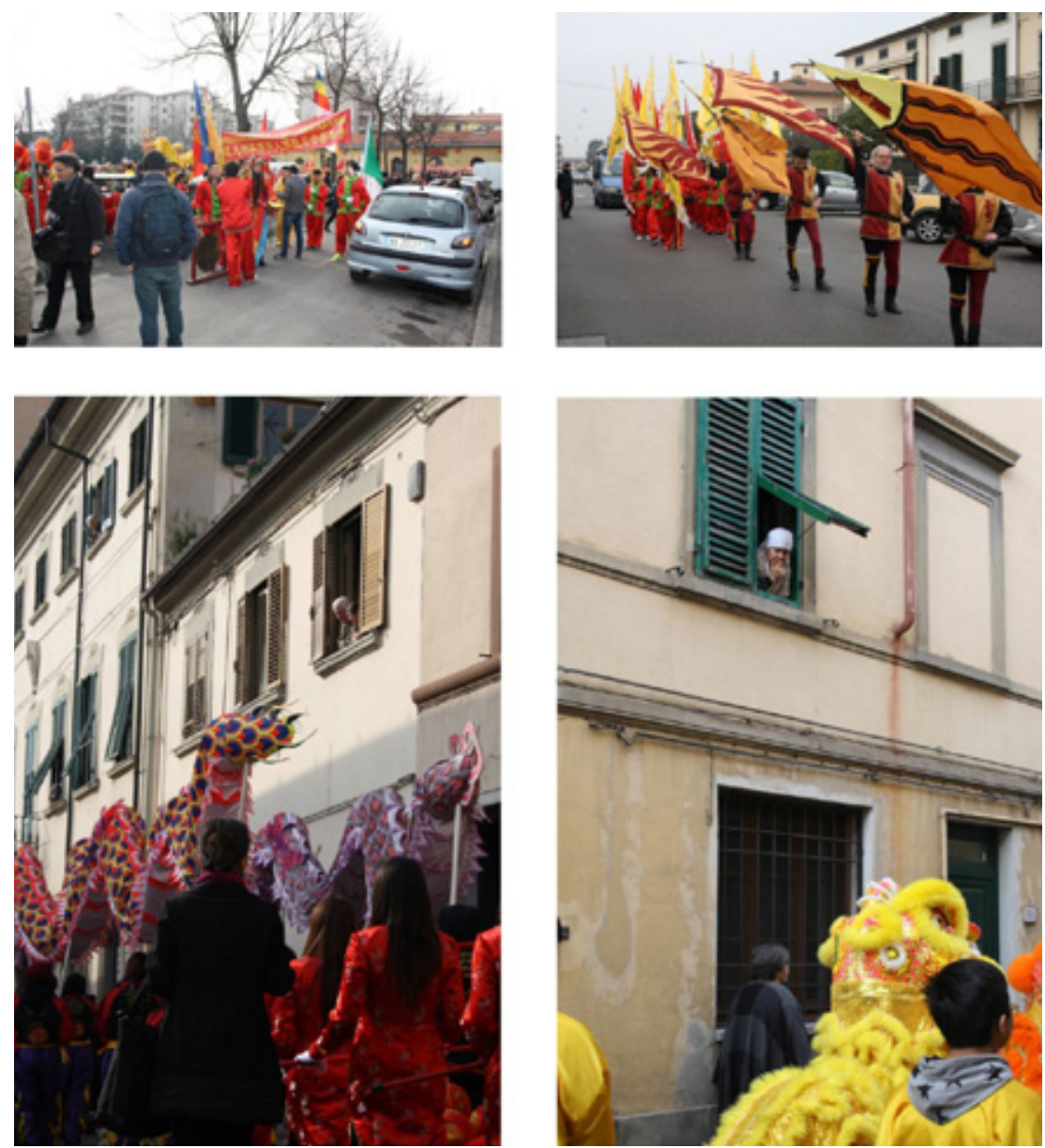

FIG. 15 The parade in the central areas of the city. Photo by Daniele Parbuono, March 1, 2015.

a lot of work-it can be a passive attitude, a human approach based on distant respect and leniency'. ${ }^{81}$

81 Wessel, 'Does Diversity', 6. 


\section{Bibliography}

An, Deming, Jessica Anderson, and Lihui Yang. Handbook of Chinese Mythology. Santa Barbara: ABC-CLIO, 2005.

Apolito, Paolo. Il tramonto del totem: Osservazioni per una etnografia delle feste [The sunset of the totem: Observations for an ethnography of the festival]. Milano: Franco Angeli, 2001.

Ariño, Antonio, and Luigi Maria Lombardi Satriani, eds. L'utopia di Dioniso: Festa tra tradizione e modernità [Dionysus's Utopia: A Feast between tradition and modernity]. Roma: Meltemi, 1996.

Arrighi, Giovanni, Arnold Leonard Epstein, and Luisa Passerini, et al. La politica della parentela: Analisi situazionali di società africane in transizione [The politics of kinship: Situational analysis of African society in transition]. Milano: Feltrinelli, 1976.

Auguin, E., Marie-Antoinette Hily, and Veronique Petit. 'Le

Nouvel An chinois à Paris: théâtre d'économies ethniques' [The Chinese New Year in Paris: theatre of ethnic economies]. Revue européenne des migrations internationales [European review of international migrations] 20, no. 3 (2004): 75-87.

Baldassar, Loretta, Graeme Johanson, Narelle McAuliffe, and Massimo Bressan, eds. Chinese Migration to Europe. Prato, Italy, and Beyond. Basingstoke-New York: Palgrave Macmillan, 2015.

Battiston, Ilaria. 'Dal Paese del Drago alla Città del Leone.

L'immigrazione asiatica a Lione vista dalla stampa locale' [From the land of the Dragon to the City of the Lion: Asian immigration to Lyon seen by the local press]. Ph.D. dissertation, University of Venezia Ca' Foscari, 2011/2012.

Berti, Fabio, Valentina Pedone, and Andrea Valzania, eds. Vendere e comprare: Processi di mobilità sociale dei cinesi a Prato [Buy and sell: The process of social mobility of the Chinese in Prato]. Pisa: Pacini, 2013.

Bianchi, Ester. Taoismo [Taoism]. Milano: Electa, 2009.

Bonato, Laura, ed. Festa viva: Continuità. Mutamento. Innovazione $I$ [Living Festival: Continuity, Change, Innovation]. Torino: Omega, 2005. 
- - - ed. Festa viva: Tradizione. Territorio. Turismo II [Living Festival: Tradition, Territory, Tourism]. Torino: Omega, 2006. Brandi, Enrico, and Sara Iacopini. 'Dal cocomero al Suv. I consumatori cinesi a Prato' [From the watermelon to the SUV: Chinese consumers in Prato]. In Vendere e comprare: Processi di mobilità sociale dei cinesi a Prato [Buy and sell: The process of social mobility of the Chinese in Prato], edited by F. Berti, V. Pedone, and A. Valzania, 135-220. Pisa: Pacini, 2013.

Bressan, M., and E. Krause. "Ho un luogo dove lavoro e un luogo dove abito": Diversità e separazione in un distretto industriale in transizione' ['I have a place where I work and a place where I live": Diversity and separation in an industrial district in transition]. Mondi Migranti. Rivista di studi e ricerche sulle migrazioni internazionali [Migrant Worlds. Journal of studies and research on international migration], no. 1 (2014): 59-81.

Bressan, M., and S. Tosi Cambini. "The "Macrolotto 0" as a Zone of Transition: Cultural Diversity and Public Spaces'. In Living Outside the Walls: The Chinese in Prato, edited by G. Johanson, R. Smyth and R. French, 149-60. Newcastle upon Tyne: Cambridge Scholars Publishing, 2009.

- - - ' Eterogeneità culturale e spazi pubblici in un distretto industriale: il "Macrolotto 0" di Prato come zona di transizione' [Cultural heterogeneity and public space in an industrial district: The "Macrolotto 0" of Prato as a zone in tradition]. In Zone di transizione: Etnografia urbana nei quartieri e nello spazio pubblico [Zone of transition: Urban ethnography in neighbourhoods and public spaces], edited by M. Bressan and S. Tosi Cambini, 203-52. Bologna: il Mulino, 2011.

Brighenti, Andrea Mubi. Visibility in Social Theory and Social Research. Basingstoke -New York: Palgrave Macmillan, 2010. Çağlar, Ayşe, and N. Glick Schiller. 'Introduction: Migrants and Cities'. In Locating Migration. Rescaling Cities and Migrants, edited by A. Çağlar and N. Glick Schiller, 1-19. Ithaca-London: Cornell University Press, 2011.

Cancellieri, Adriano, and E. Ostanel, eds. 'The struggle for public space'. City: analysis of urban trends, culture, theory, policy, action 19, no. 4 (2015): 499-509. 
Cancellieri, A., and Saint-Blancat, C. 'La scrittura religiosa della città' [The religious writing of the city]. In Tracce urbane: Alla ricerca della città [Urban traces: In search of the city], edited by A. Cancellieri and G. Scandurra, 78-86. Milano: Franco Angeli, 2012.

Ceccagno, Antonella, ed. Migranti a Prato: Il distretto tessile multietnico [Migrants in Prato: The multi-ethnic textile district]. Milano: Franco Angeli, 2003.

Celli, Nicoletta. Buddhismo [Buddhism]. Milano: Electa, 2006. Clemente, Pietro, and Fabio Mugnaini, eds. Oltre il folklore: Tradizioni popolari e antropologia nella società contemporanea [Beyond folklore: Popular traditions and anthropology in contemporary society]. Roma: Carocci, 2001.

Dikeç, M. 'Justice and the spatial imagination', Environment and Planning A: Economy and Space 33, no.10 (2001): 1785-1805.

Faeta, F. 'La festa religiosa nell'Europa meridionale contemporanea: Qualche riflessione per la definizione del suo statuto teorico' [The religious festival in contemporary southern Europe: Some reflection for the definition of its theoretical status]. In Festa viva: Continuità. Mutamento. Innovazione I [Living festival: Continuity. Change. Innovation], by Laura Bonato and Gian Luigi Bravo, 23-33. Torino: Omega, 2005.

Foucault, Michel. 'Des espaces autres' [Of other spaces]. Conférence au Cercle d'études architecturales [Conference at the Circle of architectural studies], March 14, 1967. Architecture, Mouvement, Continuité [Architecture, Movement, Continuity], no 5 (1984): 46-49.

- - Eterotopia [Heterotopia]. Milano: Mimesis, 2010.

- - - Utopie, eterotopie [Utopia heterotopia]. Napoli: Cronopio, 2006.

Gambino, Ferruccio, and Devi Sacchetto, eds. Un arcipelago produttivo: Migranti e imprenditori tra Italia e Romania [A productive archipelago: Migrants and entrepreneurs between Italy and Romania]. Roma: Carocci, 2007.

Harvey, David. Social Justice and the City. Oxford: Blackwell, 1973. Hung, Chang-Tai. 'Repainting China: New Year Prints (Nianhua) and Peasant Resistance in the Early Years of the People's 
Republic'. Comparative Studies in Society and History 42, no. 4 (2000): 770-810.

Il Tirreno Prato. 'Sfilata del Dragone in centro? È l'ipotesi allo studio dopo l'incontro tra giunta e cinesi buddisti' [A dragon parade downtown? This is the question under consideration after the meeting between the council and Chinese Buddhists]. January 5, 2015. https://iltirreno.gelocal.it/prato/cronaca/2015/01/04/ news/sfilata-del-dragone-in-centro-1.10607266.

Knott, Kim. The Location of Religion: A Spatial Analysis. London, Oakville: Equinox Publishing, 2005.

- - - 'Spatial Theory and Method for the Study of Religion'. Temenos-Nordic Journal of Comparative Religion 41, no. 2 (2005): 153-84.

Koensler, Alexander. Amicizie vulnerabili: Coesistenza e conflitto in Israele [Vulnerable friendships: Coexistence and conflict in Israel]. Perugia: Morlacchi UP, 2008.

Latham, Kevin, and Bin Wu. Chinese Immigration into the EU: New Trends, Dynamics and Implications. London: Europe China Research and Advice Network, 2013.

Lefebvre, Henri. La production de l'espace [The production of space]. Paris: Anthropos, 1974.

Leung, M. W. H. 'Rethinking "Home" in Diaspora. A Family Transnationalized? A Place of Nostalgia? A Commodity for Sale?'. In Beyond Chinatown: New Chinese Migration And the Global Expansion of China, edited by Mette Thunø, 210-33. Copenhagen: Nordic Institute of Asian Studies, 2007.

Li Minghuan. 'We need two worlds': Chinese immigrant associations in a western society. Amsterdam: Amsterdam University Press, 1999.

Liang Zai. 'Demography of Illicit Emigration from China: A Sending Country's Perspective'. Sociological Forum 16, no. 4 (2001): 677-701.

Marsden, Anna. 'L'analisi dei dati sull'immigrazione' [Analysis of immigration data]. In Migranti a Prato: Il distretto tessile multietnico [Migrants in Prato: The multi-ethnic textile district], edited by A. Ceccagno, 105-33. Milano: Franco Angeli, 2003.

Masson, Michel, Pierre-Henry De Bruyn, and Istituto Ricci, Paris, 
Taipei, et al. Grandi religioni e culture nell'Estremo Oriente: Cina [Great Religions and Cultures of the Far East: China]. Milano: Jaca Book-Massimo, 2008.

Mugnaini, Fabio. 'Feste, luoghi e patrimonio: Uno sguardo comparativo sui territori del festivo in Italia e in Europa' [Festivals, places, and heritage: A comparison of festive areas in Italy and Europe]. Lares 75, no. 2 (2009): 221-384.

Ostanel, Elena. 'Immigrazione e giustizia spaziale: Pratiche, politiche e immaginari' [Immigration and spacial justice: Practices, political and imaginary]. Mondi Migranti: Rivista di studi e ricerche sulle migrazioni internazionali [Migrant worlds. Journal of Studies and research on international migration], no. 1 (2014): $25-38$.

Palumbo, Berardino. Politiche dell'inquietudine: Passioni, feste e poteri in Sicilia [Policies of disquietude: Passion, festivals, and politics in Sicily]. Firenze: Le lettere, 2009.

Papa, Cristina, ed. Letture di paesaggi [Landscape readings]. Milano: Guerini, 2012.

Parbuono, Daniele. 'L’Umbria guarda “ancora” la Cina: Tangible e intangible: rapporti universitari e prospettive di ricerca' [Umbria "still" watches China: Tangible and intangible: university relations and research perspectives]. In L'Umbria guarda la Cina [Umbria watches China], edited by E. Bianchi and D. Parbuono, 13-43. Perugia: Morlacchi Editore, 2013.

- - . 'Storie' e Feste: Un'etnografia della comunicazione politica' ['Stories' and festival: An ethnography of political communication]. Perugia: Morlacchi University Press, 2013

_- _. 'Da Prato a Wenzhou: i pellegrinaggi dei migranti cinesi' [From Prato to Wenzhou: the pilgrimages of Chinese migrants]. In Pellegrinaggi e itinerari turistico-religiosi in Europa: Identità locali e dinamiche transnazionali [Pilgrimages and religio-tourist itineraries in Europe: Local and transnational dynamics], edited by Fiorella Giacalone, 409-24. Perugia: Morlacchi University Press, 2015.

- - - 'Il centro del centro: Il Tempio buddhista e il capodanno cinese nello spazio urbano di Prato' [The Centre of the Centre: The Buddhist Temple and the Chinese New Year in the Prato 
Urban Space]. Anuac. Rivista dell'Associazione Nazionale Universitaria Antropologi Culturali [Anuac. Magazine of the National Association of Cultural Anthropologists] 5 no. 1 (2016): 171-203.

Pirie, G. 'On Spatial Justice'. Environment and Planning A: Economy and Space 15, no. 4 (1983): 465-73.

Piselli, Fortunata, Jeremy Boissevain, et al. Reti: L'analisi dei network nelle scienze sociali [Networks: Network analysis in social sciences]. Roma: Donzelli, 1995.

Rastrelli, R. 'L'immigrazione a Prato fra società, istituzioni ed economia' [Immigration to Prato between society, institutions and the economy]. In Migranti a Prato: Il distretto tessile multietnico [Migrants in Prato: The multi-ethnic textile district], edited by A. Ceccagno, 69-104. Milano: Franco Angeli, 2003.

Redini, Veronica. Frontiere del 'made in Italy': Delocalizzazione produttiva e identità delle merci [The boundary of 'made in Italy': Delocalization of production and identity of merchandise]. Verona: Ombre corte, 2008.

Resta, Patrizia. Il vantaggio dell'immigrazione: Un progetto per una cultura condivisa [The advantage of immigration: A project for a shared culture]. Roma: Armando, 2008.

Robinowitz, Dan. Overlooking Nazareth: The Ethnography of Exclusion in Galilee. Cambridge: Cambridge University Press, 1997.

Sambo, P. 'Gli immigrati cinesi a Prato: Fotografia di una realtà in movimento' [Chinese immigrants in Prato: Photography of a reality in motion]. In Vendere e comprare: Processi di mobilità sociale dei cinesi a Prato [Buy and sell: Process of social mobility of the Chinese in Prato], edited by F. Berti, V. Pedone, and A. Valzania, 105-34. Pisa: Pacini, 2013.

Sayad, Abdelmalek, and Pierre Bourdieu. La double absence: Des illusions de l'émigré aux souffrances de l'immigré [The double absence: The illusions of the emigrant and the suffering of the immigrant]. Paris: Éditions du Seuil, 1999.

Secchi, Bernardo, ed. Un Progetto per Prato: Il Nuovo Piano Regolatore [A project for Prato: A new regulatory plan]. Prato: Alinea, 1996. 
Smith, Jonathan Z. To Take Place: Toward Theory in Ritual. Chicago and London: The University Chicago Press, 1987.

Soja, Edward W. Seeking Spatial Justice. Minneapolis and London: University of Minnesota Press, 2010.

Thunø, Mette, 'Introduction. Beyond "Chinatown": Contemporary Chinese Migration'. In Beyond Chinatown: New Chinese Migration And the Global Expansion of China, edited by M. Thunø, 1-31. Copenhagen: Nordic Institute of Asian Studies, 2007.

- - - ed. Beyond Chinatown: New Chinese Migration And the Global Expansion of China. Copenhagen: Nordic Institute of Asian Studies, 2007.

Vickery, Monica E., and A. Roy Vickery. 'Chinese New Year Celebrations in London 1971-1973'. Folklore 85, no. 1 (1974): 43-45.

Wang Jing. 'Le Nouvel An chinois à Paris: Sur les scènes de l'altérité' [The Chinese New Year in Paris: On the scenes of otherness]. Grandhiva: Revue d'anthropologie et d'bistoire des arts [Grandhiva: Review of anthropology and history of the arts], no. 17 (2013): 170-93.

Wessel, Terje. 'Does Diversity in Urban Space Enhance Intergroup Contact and Tolerance?'. Geografiska Annaler. Series B, Human Geography 91, no. 1 (2009): 5-17.

Yeh Chiou-Ling. " In the Traditions of China and in the Freedom of America”: The Making of San Francisco's Chinese New Year Festivals'. American Quarterly 56, no. 2 (2004): 395-420.

- - Making an American Festival: Chinese New Year in San Francisco's Chinatown. Berkeley: University of California Press, 2008.

Yiftachel, Oren. 'The "Internal Frontier": Territorial Control and Ethnic Relations in Israel'. Regional Studies, 30 no. 5 (1996): 493-508. 